\title{
Sürdürülebilir Mimarlık Bağlamında Metal Malzemenin Yeniden Kullanımı ve Geri Dönüşümünde Mimarın/Tasarımcının Rolü
}

\author{
Cahide AYDIN IPEKÇi ${ }^{1}$, Ayşe Feyza KARAKOÇ ${ }^{2}$ *
}

Öz

Doğal kaynakların giderek tükendiği ve çevresel sorunlar ile karşı karşıya kaldığımız bu günlerde malzemenin tüm ömrü boyunca oluşturduğu atık miktarı gün geçtikçe artmaktadır. Bu nedenle birçok alanda malzemenin yeniden kullanım ve geri dönüşüm anlayışı önem kazanmaktadır. Bu çalışmada mimaride hurda ve atık metalin yeniden kullanımı ya da geri dönüşümü üzerine farklı ülkelerdeki örneklerin incelenmesi ile mimarın/tasarımcının rolüne dikkat çekilmesi amaçlanmaktadır. Dünya'da hurda ve atık metal malzemenin yeniden kullanımı, geri dönüşümü üzerine kentsel ve mimari ölçekte örneklere rastlamak mümkündür. Türkiye'de ise bu konuda mimari çalışmalar olmasına rağmen literatüre aktarımında eksiklik olduğu düşünülmektedir. Bu çalışma ile Türkiye'de sürdürülebilir gelecek için çalışmaların yaygınlaştırılması ve mimarın/tasarımcının atık malzemenin değerlendirilmesindeki rolünün ne kadar önemli olduğu konusuna odaklanılmaktadır. Hurda ve atık metalin mimarinin bir parçası olarak tasarıma dâhil edilmesinin kaynakların korunması, malzemenin yaşam sonu depolama intiyacının azaltıması, enerji tasarrufu ve ekonomik kalkınma gibi konular üzerinde olumlu etkileri bulunmaktadır. Bu çalışma kapsamında incelenen kentsel ve mimari ölçekteki örneklerde, sürdürülebilir mimarlığın sağlanması ve çevresel problemlere farkındalık oluşturulmasının ortak amaç olduğu tespit edilmiştir. Mimarın/tasarımcının birçok projesinde farklı atık malzemeleri ve sürdürülebilir stratejileri de tasarımlarının bir parçası haline getirdikleri gözlemlenmiştir. Bu örnekler mimarın/tasarımcının atık malzemeleri tasarımlarına katması ile çevresel değişimde olumlu bir role sahip olduğunu gözler önüne sermektedir.

Anahtar Sözcükler: Hurda Metal, Geri Dönüşüm, Yeniden Kullanım, Sürdürülebilirlik, Mimarın Rolü

\section{Architect/Designer's Role on the Reusing and Recycling of Metal Materials in Terms of Sustainable Architecture}

\begin{abstract}
\footnotetext{
${ }^{1}$ Gebze Teknik Üniversitesi, Mimarlık Fakültesi, Mimarlık Bölümü, Kocaeli

${ }^{2}$ Gebze Teknik Üniversitesi, Mimarlık Anabilim Dalı, Fen Bilimleri Enstitüsü, Kocaeli

* İlgili yazar/Corresponding Author: afkarakoc@gtu.edu.tr

Gönderim Tarihi / Received Date: 22.05.2021

Kabul Tarihi / Accepted Date: 26.08.2021
}

In these days when natural resources are increasingly depleted and we are facing environmental problems, the amount of waste generated by the material throughout its entire life is increasing day by day. Therefore, the understanding of reusing and recycling of materials is gaining importance in many areas. In this study, it is aimed to draw attention to the role of the architect/designer by investigating the examples from different countries on reusing or recycling scrap and waste metal in architecture. It is possible to come across examples of the reusing and recycling of scrap and waste materials in the world, on an urban and architectural scale. Although there are architectural studies on this subject in Turkey, it is believed that there is a lack of transmission to the literature. In this study, it is focused on the dissemination of working for a sustainable future in Turkey and the importance of the architect/designer's role in the evaluation of waste materials. The inclusion of scrap and waste metal in the design 
process as a part of the architecture has a favourable impact on issues such as the protection of resources, the reduction of the material's end-of-life storage needs, energy savings, and economic development. In the examples of urban and architectural scales examined within the scope of this study, it was established that the common aim was to ensure sustainable architecture and raise awareness of environmental problems. It has been observed that the architect/designer has made different waste materials and sustainable strategies part of their design in many projects. These examples show that the architect/designer has a positive role in environmental change by adding waste material into their design.

Keywords: Scrap Metal, Recycling, Reuse, Sustainability, Architect's Role

\section{Giriş}

Sürdürülebilirlik anlayışı; hammadde ve enerji kaynaklarını korumayı hangi iklim, sosyal, ekonomik ve teknolojik şartı barındırdığı fark etmeden elde olan veriler doğrultusunda günümüz ve gelecek nesillerin intiyaçlarına duyarlı bir yaklaşım sunmaktadır. Üretim ve tüketim arasındaki dengenin kurulamaması nedeniyle tetiklenen çevresel problemlerin beraberinde popülerleşen sürdürülebilirlik anlayışı hakkında, tasarım düşüncesi açısından çok fazla içerik oluşturulmaya başlanmıştır. Bunun nedeni olarak çevre sorunlarının oluşmasında; kentlerde hızla artan nüfus, yapılaşma ve kaynakların bilinçsizce kullanımı gösterilebilmektedir. Malzemenin ve kaynakların sınırsız olmaması dolayısıyla, atıkların farklı şekillerde kullanılması gereksinimi ortaya çıkmaktadır. Miktarı gittikçe artan katı atıklar, tüketim sonrası istenmeyen, çevreyi ve toplumu olumsuz etkileme potansiyeline sahip düzenli bertaraf edilmesi gereken maddelerdir (Gündüzalp ve Güven, 2016, s. 2). "Katı atıklar; evsel katı atıklar, tıbbi katı atıklar, tehlikeli katı atıklar, inşaat atığı ve moloz (yapısal atıklar)" olarak ifade edilmektedir (Coşgun vd. 2009, s.75-78). İnşaat atığı ve yapı dışı atıklardan uygun durumda olanlar yeniden kullanılarak tasarıma dâhil edilmekte ya da geri dönüştürülerek kullanılabilmektedir. Mimaride atık malzemenin yeniden kullanımı ve geri dönüşüm etkilerinin anlaşılması, doğrudan bir yapının üç aşaması ile ilgilidir. Başlangıç aşaması, yapının inşasından önce gerçekleşir ve yapıyı oluşturacak malzemelerin nasıl elde edildiği, üretildiği ile ilgilidir. İkinci aşama binanın tüm ömrünü içerir. Son aşama ise, yapı ömrünün sona ermesidir. Bu aşamada malzemelerin çoğu toplanarak ve ayırılarak geri dönüşüme katılmaktadır (Munn ve Soebarto, 2004, s.162). Malzemenin sadece kullanım sonu çevresel etkileri düşünülmemeli, üretim, yapım, yıkım ve toplama aşamaları da dikkate alınmalıdır. Ayrıca malzemenin sürdürülebilir özelliklere sahip olmasında, kullanım ömrü sonunda yeniden kullanım ve geri dönüşüm önemli bir rol oynamaktadır. Kullanım ömrünü doldurmuş malzemelerin yapıda geri kazanımı tasarımda daha hızlı, yenilikçi, ekonomik ve ekolojik çözümleri de beraberinde getirmektedir (Kılıç, 2017, s. 533).

Günümüzde ülkelerin çevre bilincini oluşturma konusundaki politikaları ve teşvikleri giderek artmaktadır. Bununla birlikte atıkların mimarlık alanında kullanımını teşvik eden çalışmalar giderek daha da önemli bir hale gelmektedir. Bu teşvikler atık malzemelerin yeniden kullanımını ve geri dönüşümünü olumlu yönde etkilemektedir. Örneğin; malzeme üreticilerinin ve tüketicilerinin düşük ücretli kaliteli ürün istekleri geri dönüşümü yaygınlaştırmaktadır (Fırat ve Akbaş, 2015, s. 637). Doğal kaynakların sınırılığı ve çevresel problemlerin artmasıyla da oluşan bu bilinç, atık malzeme ile yenilikçi mimari çözümler geliştirilmesinin de önünü açmaktadır. "Hurda/atık mimarlığı (Junkitechture) diye adlandırılan yeni yapım şeklinde malzemeler başlangıçta hurda olmakla beraber, yeniden kullanım sonrası artık faydalı yapı malzemeleri olarak tanımlanmaktadır" (Taşçı ve Tokuç, 2015, s. 28). 
Geri dönüşümün vazgeçilmez elemanı hurda; "eski maden parçası", "parçalanmış, döküntü durumuna gelmiş" ve "işe yarayamayacak derecede bozulmuş, zarar görmüş" anlamına gelmektedir (URL-1). Bu tanımlamadan da anlaşılacağı üzere hurda kelimesi yapısal özelliklerini ve işlevini kaybetmiş malzemeleri ifade etmektedir. Başta mimarlıkta hurda metaller yapısal özelliklerini ve işlevini kaybetseler de yeniden kullanım yoluyla ya da geri dönüşüme katılarak yaşam döngüsüne dâhil edilebilmektedir. Mimarlıkta cam, seramik, tuğla, plastik gibi sıklıkla kullanılan malzemelerden biri olan metaller yüksek oranda geri dönüşüm potansiyeline sahiptir (Norgate vd. 2006, s.839). Çalışma kapsamında incelenen hurda metal, hurda kategorisinde yüksek değer ve istihdama sahip olan bir sektörü içinde barındırmaktadır. Hurda metal, geri dönüşümü en yaygın ve kazançlı malzemelerden biri olması ile diğer atıklardan farklılaşmaktadır. Bu durumun nedenlerinden biri, metal malzemenin geri dönüştürülmeden önceki ve geri dönüştürülme işleminden sonraki hali arasında yapısında değişiklik olmadan tekrar kullanılabilmesidir. Uygun durumdaki metal malzemeler yeniden kullanılırken, uygun durumda olmayan atık metal malzemeler ise eritilip şekil verilerek geri dönüşümü sağlanabilmektedir. Yapılarda geri dönüştürülmüş malzeme kullanılarak atıkların bertaraf durumunun da önüne geçilmektedir. Bu sayede hammadde kaynaklarının verimsizce kullanılması, çevre kirliliği ve ekonomik olumsuzlukların engellenmesine katkı sağlanmaktadır.

$\mathrm{Bu}$ olumsuzlukların önüne geçilmesinde, yeniden kullanım ya da geri dönüşüm anlayışının mimaride hakim olmasında ve toplumu bu konu hakkında bilinçlendirmede mimar/tasarımcı kilit taşı görevi görmektedir. Mimar, kullanıcı ile dolaylı ya da doğrudan iletişim içinde olduğundan ortaya çıkardığı yapılarda bilgi birikimini ve düşüncesini yansıtabilir (Demirarslan ve Demirarslan, 2015, s. 227). Mimar sürdürülebilir bir gelecek bırakmak için üzerine düşen sorumluluğun bilincinde olmalıdır ve bu konudaki isteğinin teşvik edilmesi gereklidir. Müşterinin talebi, yönetmelikler ve yönetimlerin desteği ile (Tuna, 2009, s.10-11) mimarın atık malzemeyi tasarımlarına dâhil edebilmesi daha kolay olacaktır. Atık malzeme kullanımı hakkında mimarın/tasarımcının bilinçlenmesi, müşteriyi de bu konuda aydınlatmasını sağlamaktadır. Mimarın yeniden kullanılabilir ve geri dönüştürülebilir malzeme tercihleri, atıkların depolama intiyacının önüne geçilmesini sağlarken sürdürülebilir mimarinin bir parçası olan atıkların azaltılması anlayışına da katkıda bulunmaktadır (Paker ve Taş, 2017, s. 90-91). Benzer şekilde yapılan çalışmalara bakıldığında mimarın/tasarımcının geri dönüştürülmüş ve/veya geri dönüştürülebilecek malzeme kullanımına olumlu baktığı ancak ikinci el malzeme konusunda kuşkuları olduğu ve kullanmadıkları anlaşılmıştır (Coşgun vd. 2009, s.75-78). Bir diğer çalışmada ise mimarın/tasarımcıların \%50'den fazlası, tasarımlarında yapım ve kullanım aşamasında oluşacak yapısal atıkları önlemeyi/azaltmayı ve bertarafını göz önüne aldıklarını belirtmişlerdir (Salgın vd. 2020, s. 448). Geri dönüştürülecek, geri dönüştürülmüş ve ikinci el malzeme kullanımının yaygınlaşması için gerekli bilgi altyapısına sahip olunması ve toplumun bilinçlendirilmesi gerekmektedir. Bu düşüncenin oluşturulmasında mimarın/tasarımcının rolü büyüktür ve tasarımlarında önyargıları yıkarak örnek olmaları gerekmektedir.

Tasarım aşamasında atık malzemenin yeniden kullanımının amaçlandığı durumdaki süreç, standart bir tasarım sürecinden önemli ölçüde farklılık göstermektedir. Mimar/tasarımcı atıkların nasıl bulunacağı, nereden temin edileceği, malzemelerin özelliklerinin ve bakım tekniklerinin araştırıması, çevresel ve sosyal kullanım senaryolarının oluşturulması ve mevzuatlara uygunluk gibi konularda bilgi eksikliği ve zorluklarla karşı karşıya kalmaktadır. Atık malzeme seçimi zaman ve maliyet açısından tasarım sürecinin olumsuz etkilenmesine neden olmaktadır. Özellikle yapısal atıkların 
kullanıldığı tasarım süreci geniş kapsamlı bir araştırma gerektirdiğinden disiplinlerarası işbirliğine intiyaç duyulmaktadır (Kozminska, 2019, s. 1-2). Tasarım aşamasındaki rol sahibi aktörlerden mimar/tasarımcı, mühendis, müşteri ve müteahhitlerin, atık malzemelerin oluşumunda ve azaltılmasında sorumluluklarının oldukça önemli olduğu ve çevresel etkiler dikkate alınmadan iyi bir proje oluşturulamayacağı unutulmamalıdır (Ahmad vd. 2016, s.4-5).

Tasarımda dikkat edilmeden yapılan seçimler ve birbirini etkileyen süreçler atık malzemenin oluşmasına ve artmasına neden olmaktadır. Bu nedenler;

- Müşteri, mimar ve müteahhit aktörlerinin dahil olduğu tasarım kararları ve iletişim eksikliği,

- Projelerde ayrıntı ve fizibilite eksikliği,

- Tasarımdaki değişimler ve yenilemeler,

- Tasarımdaki bilgi eksikliği (ön araştırma ve tasarım, uygulama, detaylandırma) ve hatalar,

- Detaylandırma eksikliği,

- Kullanım/işlev değişikliği,

- Atık yönetim planı eksikliği,

- Denetim eksikliği,

- İşçilik eksiklikleri ve hataları,

- Karmaşık tasarımlar

olarak özetlenebilir (Ahmad vd. 2016, s. 4-5; Arslan vd. 2012, s.315).

Atık oluşumuna neden olan etkenlerin belirlenmesi ne kadar önemli ise oluşacak atıkların azaltılması için belirlenecek stratejiler de yol gösterici olacaktır. Bunlar;

- Mevzuat,

- Paydaş farkındalığını arttırmak,

- Atıkların azaltılması için profesyonel kuruluşların teşvikleri,

- Tasarım yarışmaları,

- Kolaylıkla kullanılabilir atıkları araştırma ve geliştirme,

- Sahada güvenlik,

- Uygun paketleme ve nakliye ile sahadaki kaza oranlarını azaltmak,

- Sahada inşaat atıklarını ayırma,

- Uygun olmayan inşaat atıkları bertarafı konusunda katı cezalar

olarak sıralanabilir (Ahmad vd. 2016, s.6).

Çağın getirdiği tüketimdeki artış ve teknolojinin yaşamımızdaki yerine bakıldığında mimari, sadece bilirkişilerin ya da müşterilerin yorumlarından çıkarak toplumun bir parçası olmaya başlamıştır. $\mathrm{Bu}$ nedenle mimar/tasarımcıların toplumun bilinçlenmesinde ve çevresel problemler ile mücadeledeki öncü rolü gün geçtikçe artmaktadır. Mimar/tasarımcı başta bu konuda bilinçlenmeli, sonrasında müşteriye atık malzemenin kullanımında yol gösterici olmalıdır. Mimar/tasarımcı, konu hakkında ne kadar bilgi birikimine sahip olursa, şantiyede oluşan atık malzemenin tasarıma dahil edilmesini sağlamakta ve müşteriyi bu konuda bilgilendirmesi ile atık malzemenin hem kullanım olanaklarını arttırmakta hem de miktarının azaltmasında katkıda bulunmaktadır. Atık malzemenin miktarının azaltılmasında dayanıklı, çevresel etkileri düşük, geri dönüştürülmüş malzeme seçimi ve detaylandırma mimarın/tasarımcının sorumluluğundadır (Arslan vd. 2012, s.327). Ana aktörlerin başında olan mimara/tasarımcıya büyük rol düşse de yapılacak teşvikler, kısıtlamalar ve planlamalar bu süreç içindeki tüm paydaşların katılımı ile gerçekleşebilecektir. 
$\mathrm{Bu}$ çalışmada atık metal malzemelerin yeniden kullanımı veya geri dönüşümü konusunda mimarın/tasarımcının rolünün, incelenen örnekler üzerinden açıklanması amaçlanmaktadır. Bu konunun araştırıması ve analiz edilmesi tasarımlarda atık malzeme kullanımının önündeki engellerin belirlenmesine, kaldırılmasına ve dolayısıyla kullanımının yaygınlaşmasına katkı sağlayacaktır. Genellikle teknik olarak oldukça karmaşık olan tasarım sürecindeki zorluklara rağmen atık malzemelerin yeniden kullanıldığı veya geri dönüştürülerek başarıyla uygulandığı projeler bulunmaktadır. Bu kapsamda, hurda metal malzemelerin geri dönüşüm sürecinden, yaşam döngüsüne ve farklı mimarlara/tasarımcılara ait örnekler ile atık metal malzemelerin mimaride kullanımı literatür taraması yöntemi ile incelenmiştir.

\section{Hurda Metal Malzemenin Geri Dönüşüm Süreci ve Türkiye'deki Durum}

Metal; inşaat, otomobil sanayi, teknolojik aletler, rüzgâr tribünleri ve ulaşım sistemleri gibi birçok sektörde farklı amaçlarla kullanılan bir malzemedir. Mimaride ise yapının taşıyıcı elemanları, dekorasyon, çatı kaplamaları, sandviç paneller, levhalar, cephe kaplamaları, doğrama elemanları, sıhhi tesisat ve yağmur suyu boruları vb. olarak kullanılmaktadır. Metalin, farklı sektörlerde kullanım çeşitliliğine sahip olması hurda miktarını gün geçtikçe arttırmaktadır ve bu durumun sonucu olarak atık kategorisinde değerli kabul edilen hurda metal piyasası, ekonomik açıdan ülkelerin gelişmesini etkilemektedir. Hurda metal piyasasının olumlu ekonomik etkilerinin yanı sıra mimarın/tasarımcının mimaride geri dönüştürülmüş ya da geri dönüştürülme potansiyeline sahip malzeme kullanımının çevresel olumlu etkileri de sağladığı görülmektedir. Hurda metalin yeniden kullanım potansiyelinin yanında geri dönüşüme gönderildiğinde de önemli bir kaynak ve kazanç sağladığı mimar/tasarımcı tarafından unutulmamalıdır. Yeniden kullanım ve geri dönüşüm anlayışının mimaride kullanımının artmasında ve toplumsal bilincin oluşmasına katkı sağlamada, mimarın/tasarımcının bu konudaki bilgi birikiminin ülkelerin uygulamaları/teşvikleri ile desteklenmesi büyük rol oynamaktadır.

Avrupa ülkelerinde başta Hollanda ve Almanya olmak üzere, ekonomik değeri yüksek olan hurdaların yeniden kullanım ve geri dönüşüm anlayışı üzerine farklı teşvikler bulunmaktadır. Yapının yıkım aşamasından sonra tuğla, seramik, PVC, cam, mutfak malzemelerinin ikincil satışı uygulamaları yapılmaktadır. ABD'de inşaat atıklarından geri kazanılan metal ve ahşap malzeme önemli bir yer tutmaktadır ve "metal ürünlerinin geri kazanımı 18,2 ile 21,4 milyon ton arasında olup, \% 25 oranındadır" (Altındağ, 2011, s. 21). Türkiye'de ise son zamanlarda kentsel dönüşüm kapsamında artan yapısal atıkların ne olacağı ve ne şekilde geri dönüştürüleceği konusunda çalışmalar artış göstermektedir. Ülkemizde yürürlüğe girmiş yapısal atık yönetmelikleri olmasına rağmen uygulamalarında eksiklikler bulunmaktadır ve yapısal atık miktarı üzerine veri bulunmaması nedeniyle yurtdışındaki ülkeler ile bir karşılaştırma yapılamamaktadır (Buzkan ve Erman, 2020, s. 76-79).

Türkiye'deki atık/yapısal atık konusunda inşaat ve yıkım ile ilgili yönetmelik ve kanunlar bulunmakta olup 2015 yılı sonrası başta Sıfır Atık Yönetmeliği ve Atık Yönetimi Yönetmeliği olmak üzere çeşitli çalışmalar da yürütülmektedir. Bunlar;

- Çevre Kanunu

- İmar Kanunu

- Büyükşehir Belediyesi Kanunu

- Kabahatler Kanunu

- Madencilik Faaliyetleri İle Bozulan Arazilerin Doğaya Yeniden Kazandırılması Yönetmeliği 
- Atıkların Düzenli Depolanmasına Dair Yönetmelik

- Orman Kanununun 16. Maddesinin Uygulama Yönetmeliği

- Hafriyat Toprağı, İnşaat ve Yıkıntı Atıklarının Kontrolü Yönetmeliği olarak sıralanabilir (Arslan vd. 2012, s. 320-321).

Türkiye çevre mevzuatları ve yönetmelikler bakımından birçok Avrupa ülkesine göre önemli çalışmalar gerçekleştirmektedir. Ancak yönetmelik uygulamalarının hayata geçirilmemesi, çevre sorunlarının azalmasına olumlu katkılar sağlamamaktadır. Yönetmeliklerin yayınlandığı zaman diliminde uygulamaya çalışanlar olsa da, uygulamaların ertelenmesi veya kontrolünün yapılamaması bu konudaki bilincin oluşmasına engel olmaktadır. Türkiye'de yeterli teşvik, denetleme, cezai işlem yapılmaması ve bilincin eğitimler ile desteklenmemesi yönetmelik uygulamalarını olumsuz etkilemektedir (Gök 2019, s. 34-39). Bu nedenle atık malzeme konusundaki en önemli adımların başında eğitim yer almaktadır. Eğitimin, ilkokul aşamasından itibaren desteklenmesi, ayrıca mimarlık eğitiminde atık malzemenin tasarıma dâhil edilmesi durumundaki olumlu etkilerinin anlaşılması toplum ve bu konudaki aktörlerin iletişim gücünü artıracaktır. Çünkü toplumun en küçük ve en önemli yapı taşı olan ailelerin evsel atıklarından başlayarak bu konudaki bilince yeterince ulaşamaması mimarı/tasarımcıyı çeşitli kısıtlamalar içine sokmaktadır. Bu konudaki eğitim, mimarın/tasarımcının kullanıcı ve müşteri arasındaki ilişkisini doğrudan etkilemektedir.

Türkiye'de yapısal atık malzemelerin kullanımı, denetlemesi, uygulanması vb. üzerine birçok engel bulunmasına rağmen, yapının yıkımından itibaren hurda metal geri dönüşüm tesisleri ve üretim firmaları bulunmaktadır. Geri dönüşüm tesislerinde hurda metallerin yerinde alımı/kesimi ve satımı tehlikesiz hurda metallerin satışı, atık ara depolama, atık geri kazanımı, tesis/yapı yıkımı ve söküm işlemleri yapılmaktadır. Aynı zamanda tesislerde yapı yıkımından, ahşap, pvc pencereler, banyo mutfak dolapları, armatürler, yangın merdiveni, hurda çatı sacı, cam, plastik, alüminyum, bakır alımı ve geri dönüşümü yapılmaktadır Bu sayede hurda metal malzemenin yapının yıkım aşamasında toplanması ve tesislerde geri dönüşüm işlemlerinden sonra piyasaya tekrar kazandırılması sağlanmaktadır. (URL-2, URL-3, URL-4, URL-5). Hurda metalin, ilk özelliklerini kaybetmeden tekrar geri dönüştürülme potansiyeli sayesinde inşaat atıklarından büyük oranda geri kazanılmaktadır. Bir yapı ömrünün sonuna geldiğinde, metal yapı elemanlarının büyük bir kısmı doğrudan yeniden kullanılabilmekte veya geri dönüştürülüp yaşam döngüsüne dâhil edilebilmektedir. Uzun ömürlü ürünler malzeme kullanım miktarının azaltılmasını sağlarken, yeniden kullanım ve geri dönüşüm yeni hammadde girdilerinin ve atık çıktılarının azaltılmasına da katkıda bulunmaktadır (Norgate vd. 2006, s. 839).

Metal yapı malzemeleri yaşam döngüsü; hammaddelerin çıkarımı, metallerin kolay şekil alabilmesi için levha, boru gibi formlarda üretiminin sağlanması, oluşturulan metal malzeme ile yapı elemanları üretimi, inşaat, kullanım, söküm işlemleri, ayırma ve geri dönüştürülerek üretim aşamasına katılması ile 'beşikten beşiğe' şeklinde sağlanmaktadır (Şekil 1). Yapılarda kullanılan metal ürünlerin \% 95'inden fazlası kullanım ömrü sonunda toplanmaktadır. Küçük ve orta ölçekli şirketler, metal geri dönüşüm döngüsündeki görevleri ile metallerin toplanması ve işlenmesinde önemli bir rol oynamaktadır. Metal geri dönüşümü, birincil üretime göre enerji tasarrufu sağladığı için ekonomik olduğu kadar çevresel olumlu etkileri de bulunmaktadır (European Metals Associations, 2011, s. 3). 


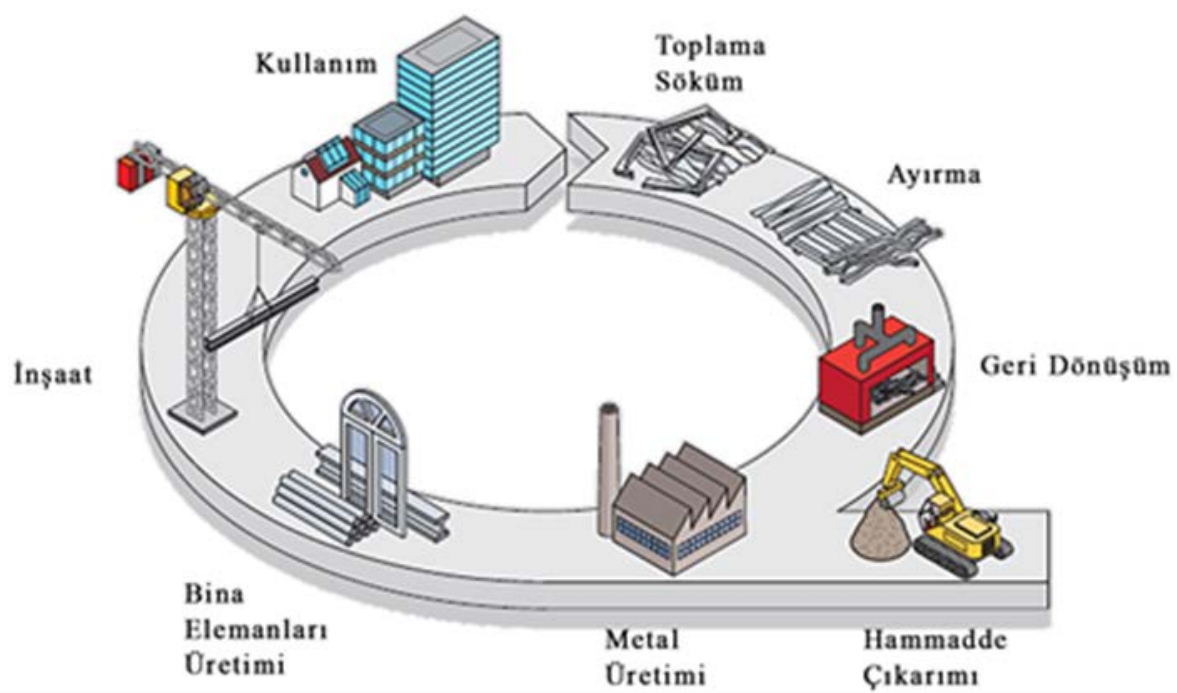

Şekil 1: Metal malzemenin yaşam döngüsü (European Metals Associations, 2011, s. 3)

Geri dönüşüm işlemi ile hurda metal, ikincil hammadde kaynağı haline gelmektedir. Bu durum metal sektöründe hammadde kaynaklarının korunmasını sağlamaktadır. Hurda metaller; yeni hurda, eski hurda ve tesis hurdası olarak sınıflandırılmaktadır. Tesis hurdası, demir-çelik üretimi sırasında tesiste oluşmaktadır ve toplanarak geri dönüşümde kullanılmaktadır. Yeni hurda, diğer demir-çelik malzeme üretim tesisinden elde edilmektedir ve hurda bayilerinden alınmaktadır. Yeni hurdanın kullanımı ve elde edilmesi tesis hurdasına göre daha uzundur. Eski hurda, kullanım ömrünü tamamlamış ve araç, yapı, makine gibi yararlı hizmetlerden elde edilen metal malzemelerden elde edilmektedir. Eski hurda, yeni ve tesis hurdasına göre malzemenin kullanım ömrü sonucu oluştuğu için elde edilmesi en çok zaman alan hurdadır (Öcal, 2014, s. 68-69). Metal üretimi sırasında atık olarak oluşan cüruf ise farklı sektörlerde ikincil bir ürün olarak kullanılmaktadır.

Hurda metal geri dönüşüm süreci; hurda metallerin toplanması, ayrılması, işlenmesi, eritilmesi, katılaştırılması evrelerinden sonra üretim aşaması için metal çubuklar haline getirilmesini takip etmektedir. Yapı inşaatı için üretime katılan metal malzeme kullanım ömrünün sonunda yıkım/söküm işlemlerini takiben tekrar geri dönüştürülerek üretime katılabilmektedir (URL-6) (Şekil 2).

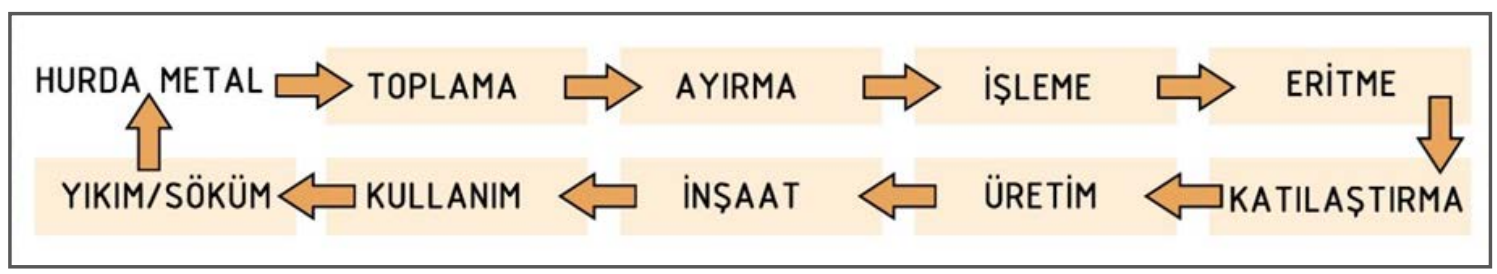

Şekil 2: Hurda metal geri dönüşüm süreci (URL-6 kaynağından düzenlenmiştir)

Hurda metal, rengi veya ağırlığına bakılarak manuel ya da mıknatıs yöntemi ile manyetik ayırma işleminden geçirilmektedir. Daha fazla işlem yapılabilmesinin sağlanması ve eritme aşamasını desteklemesi için parçalara ayrılarak fırında eritilmektedir. Eritme işleminden sonra metalden kirletici içermemesi için arıtma işlemi gerçekleştirilmekte ve katılaştırımaktadır. Katılaştırma işlemi ile metal malzemeden istenilen özel şekiller (çubuklar, borular, teller vb.) oluşturulmaktadır. Oluşturulan bu metal ürünlerin kullanılacağı fabrikalara ulaşımı sağlanmaktadır. Metal malzemeler kullanım ömrü sonunda tekrar bu aşamalardan geçerek geri dönüşüm işlemleri 
tekrarlanmaktadır (URL-6). Hurda metal malzemelerin ve diğer atıkların geri dönüştürme işlemleri hammadde ihtiyacını azaltarak kaynakların korunmasını sağlamaktadır. En uygun şekilde geri dönüşümü sağlanan atık malzemelerin ekonomik (iş gücü), çevresel (birincil hammadde temini intiyacının azaltılması, atmosferdeki $\mathrm{CO}_{2}$ miktarındaki azalma) ve enerji tasarrufu gibi konulara katkılar sağladığı görülmektedir.

\section{Atık Metal Malzemelerin Mimaride Kullanımı Üzerine Örnekler}

Malzemenin kullanım sonu toplama işleminden sonra herhangi bir işleme maruz kalmadan yeniden kullanım yoluyla ya da toplama, ayırma ve geri dönüştürülme işlemi sonrasında kentsel/mimari projelerde kullanılması mümkündür. Mimar/tasarımcı atığa değer katarak yaratıcı ve ilgi çekici tasarımlar ortaya çıkarmaktadır. Atık malzemenin yeniden kullanımı ya da geri dönüşümü ile yapılan projelerin, çevresel faydalarına ek olarak toplumu bilinçlendirdiği de görülmektedir ve bu farkındalığın oluşmasında mimara/tasarımcıya önemli görevler düşmektedir. Mimari ve kentsel ölçekteki projelerde sıklıkla kullanılan atık malzemeler plastik ve cam şişe, kâğıt bardak, palet, araba lastiği, konteyner gibi yapı dışı elamanlardır. Bu kullanımın dışında yapılardan elde edilen kapı, evye, kiremit gibi malzemelerin de kullanıldığı örnekler bulunmaktadır. Atık malzemelerin tekrar kullanımı ile gerçekleştirilen örnekler incelendiğinde "modüler, düşük maliyetli, sürdürülebilir malzemeler kullanıldığından" çevresel, ekonomik ve toplumsal olumlu etkileri olduğu görülmektedir (Tandoğan, 2018, s. 189).

Bu çalışma kapsamında farklı sektörlere ait ve değersiz olarak kabul edilen atık metal malzemelerin yer aldığı 10 adet proje incelenmiştir. Bu projelerde kullanımını yitirmiş gemi, yatak, uçak, evye, otomobil, sac plaka parçalarının ve konteynırın nasıl değerlendirildiği incelenmiştir (Tablo 1).

Tablo 1. Atık metal malzemelerin kullanıldığı proje örnekleri

\begin{tabular}{|l|l|l|l|l|}
\hline $\begin{array}{c}\text { Proje Adı/Yapım } \\
\text { Yılı/ Yeri }\end{array}$ & $\begin{array}{l}\text { Projenin } \\
\text { Türü ve } \\
\text { Işlevi }\end{array}$ & $\begin{array}{c}\text { Mimarl } \\
\text { Tasarımcı/ } \\
\text { Mimarlık Ofisi }\end{array}$ & $\begin{array}{c}\text { Atık Metal } \\
\text { Malzeme } \\
\text { Türü }\end{array}$ & $\begin{array}{c}\text { Atık Metal } \\
\text { Malzemenin } \\
\text { Kullanım Şekli }\end{array}$ \\
\hline $\begin{array}{l}\text { Recycloop/ } \\
\text { Hollanda/2009 }\end{array}$ & Pavilyon & $\begin{array}{l}\text { 2012 Architecten/ } \\
\text { Superuse Studios }\end{array}$ & Evyeler & $\begin{array}{l}\text { Yeniden Kullanım } \\
\text { (cephe elemanı) }\end{array}$ \\
\hline $\begin{array}{l}\text { The Luxury } \\
\text { (Abwab)Pavilyon/D } \\
\text { ubai/2011 }\end{array}$ & $\begin{array}{l}\text { Pavilyon- } \\
\text { Sergi }\end{array}$ & $\begin{array}{l}\text { Fahed+ } \\
\text { Architects }\end{array}$ & $\begin{array}{l}\text { Helezon } \\
\text { Yatak Yayı } \\
\text { (form ve yullanım } \\
\text { kabuğu) }\end{array}$ \\
\hline $\begin{array}{l}\text { House/United } \\
\text { States/2011 }\end{array}$ & Konut & $\begin{array}{l}\text { David Hertz } \\
\text { Architects }\end{array}$ & Hurda Uçak & $\begin{array}{l}\text { Yeniden Kullanım } \\
\text { (çatı, çatı } \\
\text { penceresi, peyzaj } \\
\text { elemanı) }\end{array}$ \\
\hline $\begin{array}{l}\text { Konteynır Park/ } \\
\text { Izmir/2015 }\end{array}$ & Teknopark & Atölye Mimarlık & Konteynır & $\begin{array}{l}\text { Yeniden Kullanım } \\
\text { (işlev değişikliği) }\end{array}$ \\
\hline $\begin{array}{l}\text { Doğuş Lojistik D } \\
\text { Kafe/ } \\
\text { Kocaeli/2015 }\end{array}$ & $\begin{array}{l}\text { Sosyal } \\
\text { Işlev-Kafe }\end{array}$ & Muum Mimarlık & Çelik Plakalar & $\begin{array}{l}\text { Geri dönüs̆üm } \\
\text { (yapı kabuğu ve } \\
\text { gölgeleme } \\
\text { elemanı) }\end{array}$ \\
\hline $\begin{array}{l}\text { Temp'I (Temporary } \\
\text { Temple)/ } \\
\text { Güney Kore/2016 }\end{array}$ & Pavilyon & $\begin{array}{l}\text { Shinslab } \\
\text { Architecture }\end{array}$ & $\begin{array}{l}\text { Paslanmış } \\
\text { Gemi } \\
\text { Parçaları }\end{array}$ & $\begin{array}{l}\text { Yeniden Kullanım } \\
\text { (yapı kabuğu) }\end{array}$ \\
\hline $\begin{array}{l}\text { Casa Pollo/ } \\
\text { Şili/2016 }\end{array}$ & Konut & $\begin{array}{l}\text { Ortuzar Gebauer } \\
\text { Arquitectos }\end{array}$ & $\begin{array}{l}\text { Eski Çinko } \\
\text { Plakalar }\end{array}$ & $\begin{array}{l}\text { Yeniden Kullanım } \\
\text { (cephe elemanı) }\end{array}$ \\
\hline $\begin{array}{l}\text { Waste Delivery } \\
\text { Station/ } \\
\text { Hollanda/2017 }\end{array}$ & Atık & Superuse Studios + \\
İstasyonu & $\begin{array}{l}\text { Otomobil } \\
\text { Sessel Van Geffen } \\
\text { Sanayi Çelik } \\
\text { Sac Plakaları }\end{array}$ & $\begin{array}{l}\text { Yeniden Kullanım } \\
\text { (cephe elemanı) }\end{array}$ \\
\hline
\end{tabular}




\begin{tabular}{|l|l|l|l|l|}
\hline $\begin{array}{l}\text { Uçak } \\
\text { Restoran/Kafe } \\
\text { Konya/Balıkesir } \\
\text { Tekirdağ/Kayseri }\end{array}$ & $\begin{array}{l}\text { Restoran/ } \\
\text { Kafe }\end{array}$ & ----------------- & Hurda Uçak & $\begin{array}{l}\text { Yeniden Kullanım } \\
\text { (işlev değişikliği) }\end{array}$ \\
\hline $\begin{array}{l}\text { La Paisanita } \\
\text { Refuge/ } \\
\text { Arjantin/2020 }\end{array}$ & $\begin{array}{l}\text { Konut- } \\
\text { Barınak }\end{array}$ & STC Arquitectos & $\begin{array}{l}\text { Petrol } \\
\text { Boruları ve } \\
\text { Oluklu Metal } \\
\text { Levha }\end{array}$ & $\begin{array}{l}\text { Yeniden Kullanım } \\
\text { (çatı, cephe ve } \\
\text { taşıyıcı sistem } \\
\text { elemanı) }\end{array}$ \\
\hline
\end{tabular}

\subsection{Recycloop projesi (Hollanda)}

'2012 Architecten' ve 'Superuse Studios" ofisi tarafından yapılan tasarımda malzemenin yeniden kullanımı ve geri dönüşümü çok önemli bir yer tutmaktadır. 'Superuse' anlayışının fikir babası olan Mimar Cesare Peeren ve 2012 Architecten mimarları malzemelerin geri kazanımı konularına odaklanmaktadır. İklim değişimi ve kaynakların tükenme sorunu karşısında mimaride yeni yaklaşımların ortaya çıkması gerektiğini (URL-7) savunan Peeren'in 'Superuse' felsefesi;

- Mevcut malzemeler ile dönüşümün sağlandığı,

- Atık diye bir şeyin olmadığı her malzemenin bir potansiyele sahip olduğu,

- Az kullanılan ya da israf edilecek kaynakların kullanılması gerektiği,

- Atık malzeme özelliklerinin iyi incelenmesi ve uygun olanların tasarımı etkilemesine izin verilmesi gerektiği,

- Proje alanına yakın yerlerden elde edilen atık malzemelerin kullanılması gerektiği,

- Her bir malzemenin birden fazla işlevi yerine getirme potansiyeli olduğunu ve bu potansiyeller incelenerek tasarımla entegre çalışmalar yapılabileceğini,

- Gereksiz enerji ve kaynak kullanımını azaltmak veya ortadan kaldırmayı kapsamaktadır (URL-8).

Bu felsefe doğrultusunda 2009 yılında Utrecht festivalinde kullanılmak üzere tasarlanan Recycloop Projesi 'Junkitechture' olarak ifade edilen ve atık malzemenin faydalı kullanımlar haline getirildiği mimari yaklaşımı içeren projelere örnek olarak gösterilmektedir. Metal taşıyıcı elemanlar ve yalıtım levhaları ile desteklenen kullanılmış mutfak evyeleri çok amaçlı kültür merkezinin pavilyon inşasında kullanılmıştır (URL-9). Geri kazanılan metal evyeler çok fonksiyonlu pavilyonun cephesini oluşturmakta ve farklı şekillerde yerleşimi montaj kolaylığı sağlamaktadır (Şekil 3a-3b). Bununla birlikte su deposunda toplanan yağmur sularının peyzaj sulamasında kullanılması (URL-10) pavilyon tasarımda sürdürülebilir yaklaşımların da düşünüldüğünü göstermektedir. Kullanım sonu pavilyon malzemeleri sökülerek Hollanda'da farklı yerlerde yeniden kullanılmıştır.

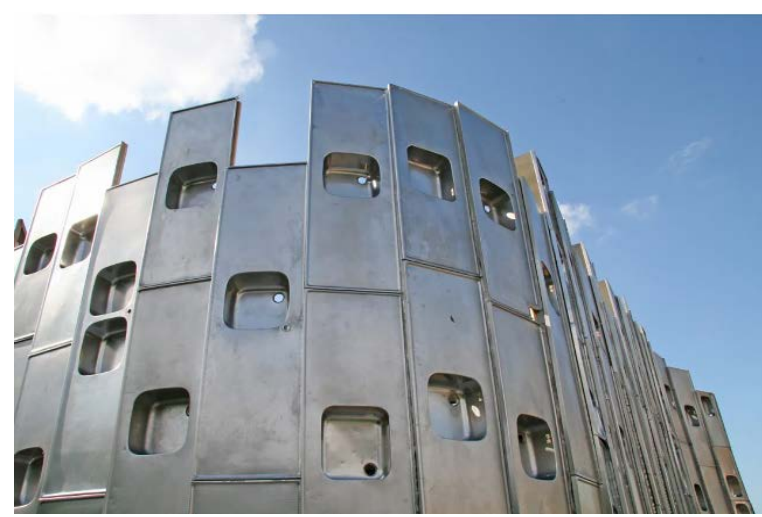

Şekil 3a. Recycloop dış görünüş (URL-11)

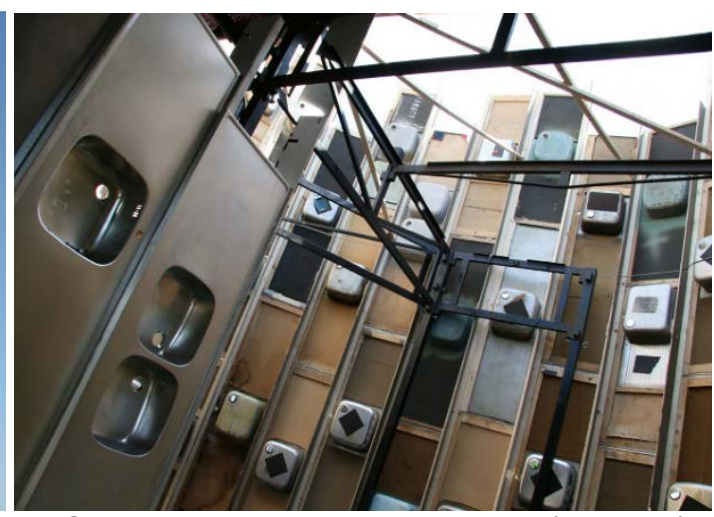

Şekil 3b. Recycloop iç görünüş (URL-11) 


\subsection{Luxury Pavilyon projesi (Dubai)}

Luxury Pavilyon, 2011 yılında Dubai Tasarım haftasında, çevreye saygılı tasarım anlayışına sahip Fahed+Arcitects ofisi ve yerel atık yönetim şirketi Bee'ah'ın işbirliği ile tasarlanmıştır. Pavilyonun formu geri dönüştürülebilir 1100 adet yatak yayı kullanılarak oluşturulmuştur ve çevrede bulunan yapı yoğunluğunun içinde organik bir görüntü sağlanmıştır (Şekil 4a). Işık, pavilyonun gözenekli ve geçirgen yapısı sayesinde içeriye alınmakta ve sergi fonksiyonunun etkileşimini güçlendirmektedir (URL-12) (Şekil 4b).

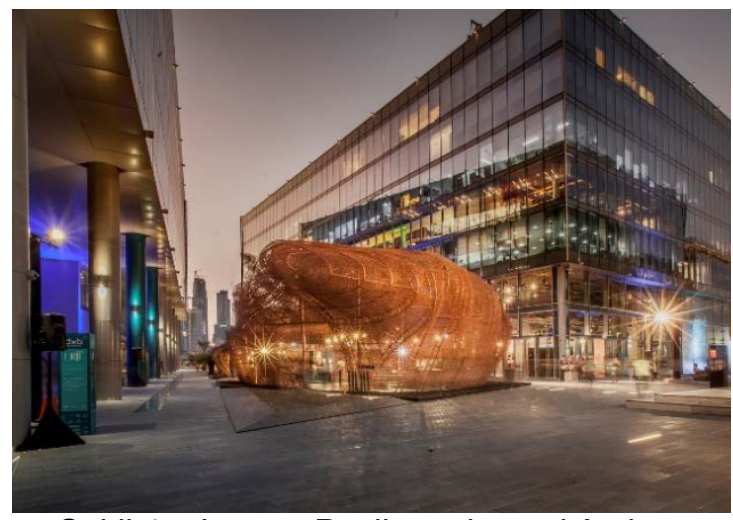

Şekil 4a. Luxury Pavilyon dış mekândan görünüş (URL-12)

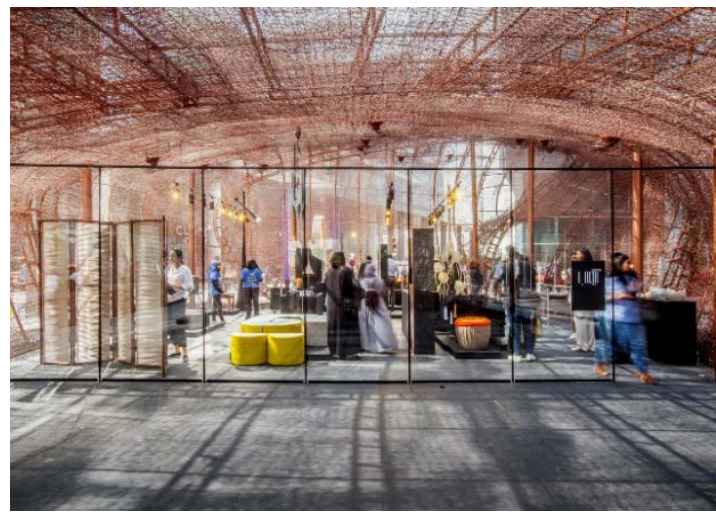

Şekil 4b. Luxury Pavilyon iç mekandan görünüş (URL-12)

Tasarım, kullanım ömrü sonunda atık malzemenin potansiyelini sergileyerek Dubai'ye anlamlı bir geri dönüşüm projesi sunmaktadır. Sergi sonunda pavilyonda kullanılan malzemeler atık yönetim merkezi Bee'ah'e geri dönüştürülmek için gönderilerek "pavilyon sürdürülebilirlik kavramıyla başlar ve biter" temasının uygulandığı görülmektedir (URL-13). Herhangi bir atık malzemenin işlevi önemli olmadan sahip olduğu yeniden kullanım ve/veya geri dönüşüm potansiyeli sayesinde deneyimlere açık mimari mekânlar oluşturmanın da mümkün olduğu görülmektedir.

\subsection{Wing House projesi (United States)}

747 Wing House, yeniden kullanıma uygun veya geri dönüştürülmüş malzemeleri projelerinde sıklıkla kullanan David Hertz Architects Ofisi tarafından ABD'de 2011 yılında inşa edilmiştir (URL-14). Mimarların farklı nesneleri tasarımlarına dâhil etme amacı, manzaradan maksimum şekilde yararlanma isteği ve müşterinin eğrisel çatı talebi üzerine uçak kanatlarının çatı malzemesi olarak kullanılması fikri ortaya çıkmıştır. Mimarlar tarafından satın alınan uçak parçalarının tümünün projede kullanıımaya çalışılması tasarımda atık yönetiminin planladığını göstermektedir. Mimarların tasarımlarının başından itibaren sürdürdükleri çevreci yaklaşım sayesinde her bir parça değerlendirilerek atık oluşumunun önüne geçilmiştir. Uçağın kabin güvertesi parçaları konuk evinin çatısında, kokpit pencereleri bir çatı penceresinde ve motor kaputu parçaları evin bahçesinde oluşturulan şömine de kullanılarak geri kazanılmıştır (URL15) (Şekil 5a-5b). 


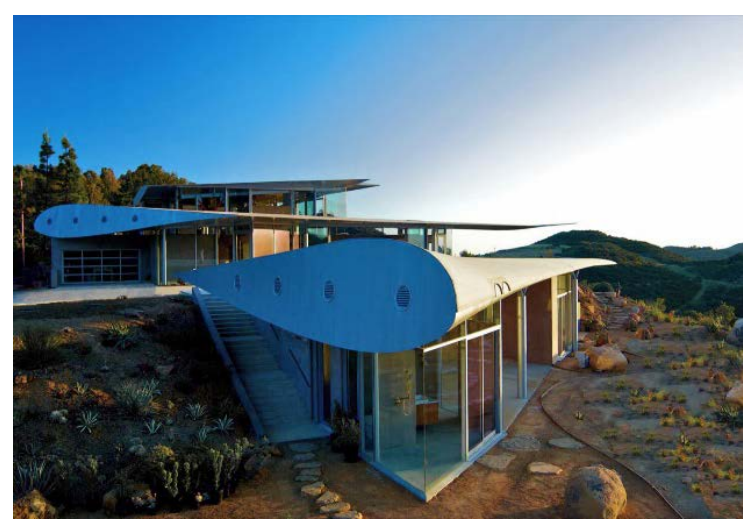

Şekil 5a. 747 Wing House dış mekândan görünüş (URL-15)

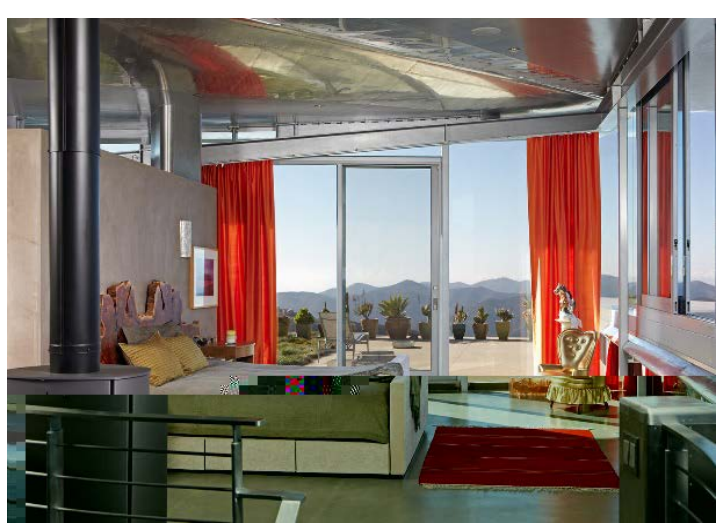

Şekil 5b. 747 Wing House iç mekândan görünüş (URL-15)

\subsection{Konteynır Park projesi (İzmir)}

Konteynır Park projesi 2015 yılında İzmir'de Atölye Mimarlık tarafından tasarlanan ARGE kompleks yapısıdır ve 35 adet ikinci el konteyner kullanılarak inşa edilmiştir (Şekil 6a-6b). Tasarımın hızlı inşa edilebilir ve taşınabilir niteliklere sahip olması talebi üzerine proje konumunun mevcut potansiyellerini ortaya çıkarmak üzerine çalışmalar yapılmışır (URL-16). Projenin yakın konumunda İzmir limanı bulunması ikinci el konteynır kullanımını cazip hale getirmiştir. Mimarın/tasarımcının malzeme seçimi ve talep edilen intiyaçlar üzerine titiz çalışmalar yaptığı görülmektedir. Alanda bulunan yıkımış yapı temelleri üzerine, mevcut ağaçlar, güneşin geliş açısı ve hakim rüzgar yönü de dikkate alınarak konteynırlar yerleştirilmiştir (URL-17). İkinci el konteynırlardan yararlanılarak atık malzemenin yeniden kullanımı sağlanırken, soğuk çatı, yeşil duvar, solar cam ve izolasyon uygulamaları ile enerji kullanımının azaltıması da sağlanmaktadır. Bununla birlikte pasif ve aktif sistemlerden; doğal havalandırma, baca etkisi, gölgelendirme elamanı ve led aydınlatma kullanımaktadır (URL-18).

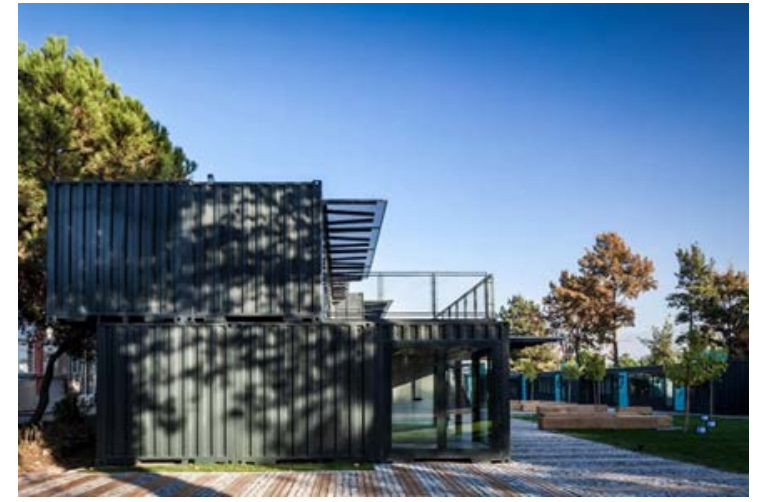

Şekil 6a. Konteynır Park genel görünüş (URL-18)

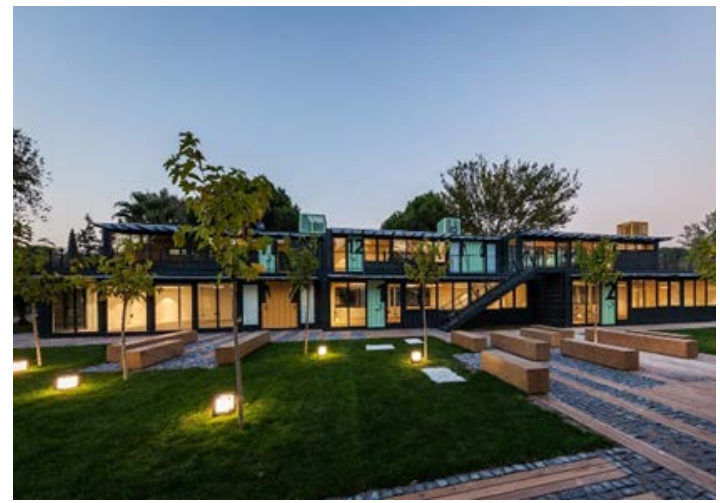

Şekil 6b. Konteynır Park genel görünüş

(URL-18)

\subsection{Doğuş Lojistik D Kafe projesi (Kocaeli)}

Doğuş Lojistik D Kafe Projesi, 2015 yılında Kocaeli'nde Muum Mimarlık tarafından inşa edilmiştir. Doğus Lojistik kampüsünde çalışanlar için oluşturulan kafe, iç-dış mekân arasında doğal ışıktan ve manzaradan yüksek oranda yararlanmak için şeffaflık dikkate alınarak tasarlanmıştır (Şekil 7a). Projede kullanılan delikli çelik plakaların bıraktığı ısıı ve gölge ile farklı yüzey etkileri oluşturmaktadır (Şekil 7b). Geri dönüşüm işlemi sonucunda elde edilen çelik plakalar, yapı kabuğunu çevreleyerek gölgelendirme işlevini sağlamaktadır (URL-19). 


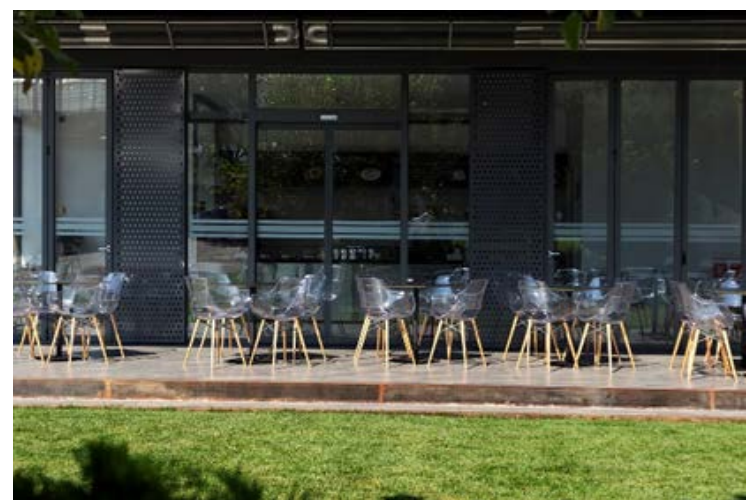

Şekil 7a. Doğuş Lojistik D Kafe genel görünüş (URL-19)

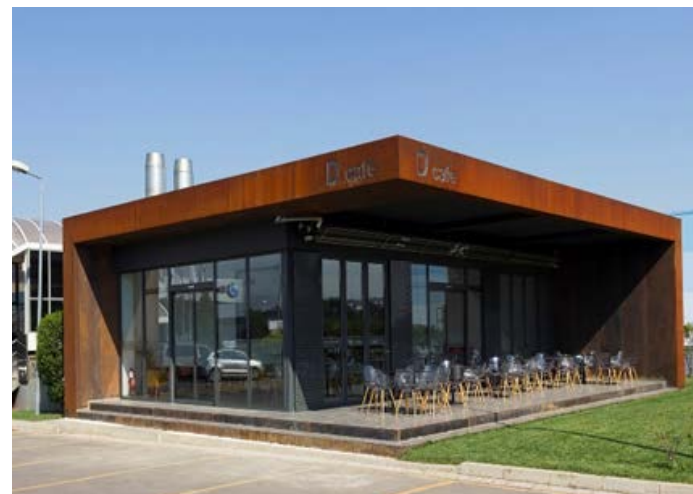

Şekil 7b. Doğuş Lojistik D Kafe genel görünüş (URL-19)

Çelik gibi metal malzemelerin yeniden kullanımına ek olarak yüksek geri dönüşüm potansiyeline sahip olduğu hatırlatan Doğuş Lojistik D Kafe Projesi, geri dönüştürülmüş metal malzeme kullanılmasının yaygınlaştırılması bakımından örnek teşkil etmektedir.

\subsection{Temp'l projesi (Güney Kore)}

Temp'l (Geçici Tapınak) Projesi, 2016 yılında Güney Kore'de Shinslab Architecture Ofisi tarafından MoMA Genç Mimarlar Programı için tasarlanmıştır. Projenin oluşturulmasındaki amaç, işlevini kaybetmiş atık malzemenin boyutu ve türü önemli olmadan sahip oldukları yüksek geri dönüşüm potansiyelini göstermektir (URL-20).

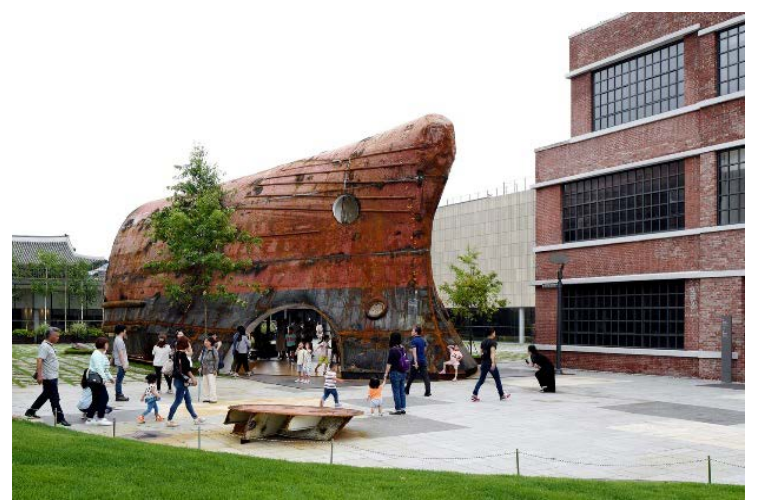

Şekil 8a. Temp'l genel görünüş (URL-21)

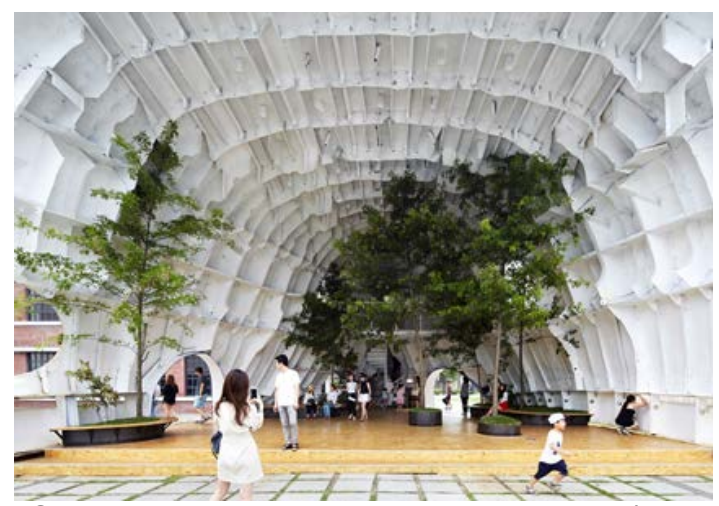

Şekil 8b. Temp'l iç mekandan görünüş (URL-

21)

Pavilyon, kullanım ömrü sonuna gelmiş bir geminin çelik parçaları kullanılarak tasarlanmıştır. Hurda geminin ön kısmının kesilmesi ve kütlenin boşaltılması ile elde edilen parçadan kentsel ölçekte bir mekân oluşturulmuştur. Kore Ulusal Modern ve Çağdaş Sanatlar Müzesi'nin giriş avlusunda bulunan gemi parçası ziyaretçiler için merak uyandırmaktadır ve paslı dış görüntüsünün arkasında ağaç ve bitkilerle dolu bir dinlenme mekânı sunmaktadır (Şekil 8a-8b). Temp'L projesi ile sadece mimaride geri dönüştürülmüş malzeme kullanarak yeni bir yaklaşım ortaya koymayı değil, aynı zamanda mekân-kullanıcı arasında yeni duygular oluşturulmasını da değerli bulunmaktadır (URL-21). Tasarım aşamasından itibaren atık malzemenin potansiyel güzelliğini sergilenmenin ve toplumsal bilincin oluşmasının önemsendiği bu projenin, konu üzerinde olumlu etki oluşturmaya katkı sağladığı düşünülmektedir. 


\subsection{Casa Pollo projesi (Şili)}

Casa Pollo yazlık ev projesi 2016 yılında Şili'de Ortuzar Gebauer Arquitectos Ofisi tarafından Caicawe Kanalı'nın kenarında inşa edilmiştir. Eski inşaatlardan elde edilen kullanım ömrünü tamamlamış çinko plakalar dış cephede yeniden kullanılmaktadır ve oksitlenen görüntüsü ile peyzajın bir parçası haine gelmektedir (URL-22) (Şekil 9a). Cephede eski çinko plakalar kullanılmasına rağmen, Casa Pollo evi yeni ve modern bir görüntü sergilemektedir. İç mekânda ise zeminde, kapılarda ve kaplamalarda ahşap malzeme yeniden kullanılmaktadır (URL-23) (Şekil 9b).

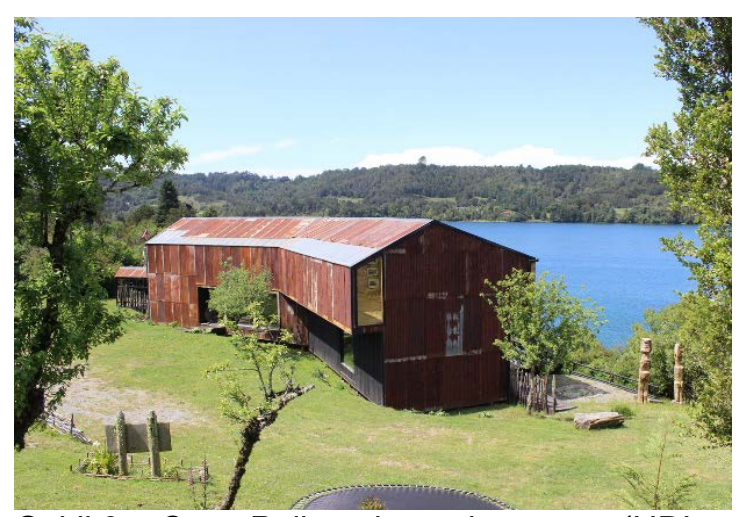

Şekil 9a. Casa Pollo evi genel görünüş (URL23)

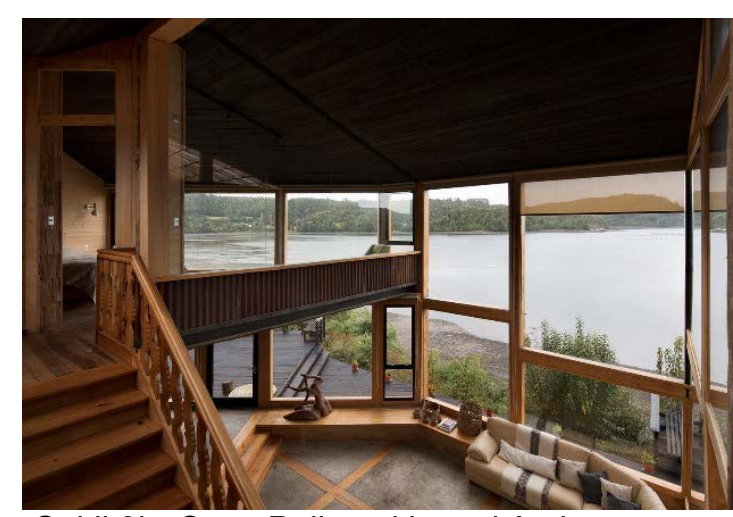

Şekil 9b. Casa Pollo evi iç mekândan görünüş (URL-23)

\subsection{Waste Delivery Station projesi (Hollanda)}

Waste Delivery Station projesi, Wessel Van Geffen Architecten ve Superuse Studios işbirliği ile Hollanda'da 2017 yılında inşa edilmiştir. Belediyenin proje için, kendi enerjisini karşılaması ve geri dönüştürülmüş malzemelerin mümkün olduğunca kullanılması talebi tasarım anlayışını yönlendirmiştir. Bu amaçla "geleneksel tasarım süreci tersine çevrilmiştir: mimarın başlangıç noktası form değil, mevcut malzemeler" olarak belirlenmiştir (URL-24).

Otomobil endüstrisinde atık malzeme olan galvanizli çelik sac plakalar cephe malzemesi olarak kullanılmıştır ve cephenin ses geçirmez olması gereken yerlerinde kullanılan sandviç paneller yıkılmış yapılardan elde edilmiştir (Şekil 10a). Sac plakaların sahip olduğu farklı kesim ve boşluklar ile cephede birbirini tekrarlamayan görüntüler oluşturmaktadır (Şekil 10b). Atık malzemelerin kullanımının yanı sıra enerji üretimi için güneş panellerinin bulunduğu, yağmur suyunun toplandığı ve kullanıldığı sürdürülebilir yaklaşımlar da projede kullanılmaktadır (URL-25). Waste Delivery Station projesi, mimaride atık malzemenin kullanıımasında mimarın/tasarımcının ve müşterinin işbirliğinin ne kadar önemli olduğunu göstermektedir. Aynı zamanda geri dönüşüm tesisi, atık toplama merkezi ve geri dönüşüm müzesi gibi işlevlerde atık malzemelerin tercih edilmesi ile topluma verilmeye çalışılan konu hakkındaki mesajın daha anlamlı olacağı düşünülmektedir. 


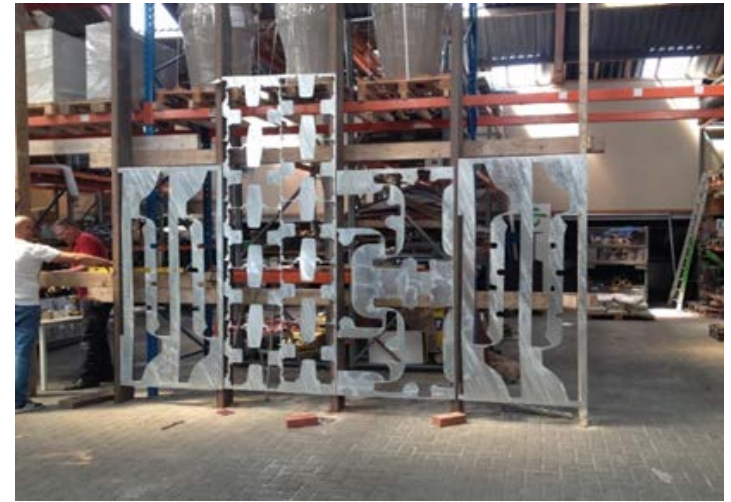

Şekil 10a. Waste Delivery Station genel görünüş (URL-24)

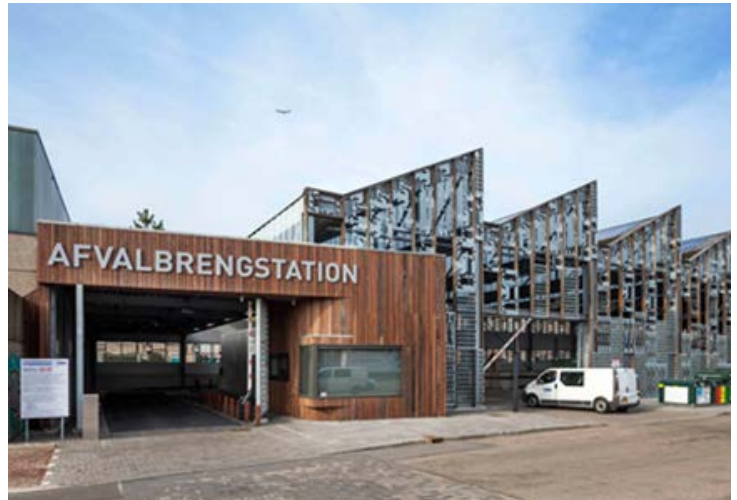

Şekil 10b.Waste Delivery Station cephe malzemesi (URL-25)

\subsection{Uçak Restoran/Kafe projesi (Konya, Balıkesir, Tekirdağ, Kayseri)}

Balıkesir-Burhaniye, Konya, Tekirdağ, Kayseri gibi şehirlerde hurda uçak kullanılarak oluşturulan restoran/kafe projeleri bulunmaktadır. THY'nin uçuş ömrünü dolduran Balıkesir'de Airbus A 340, Konya, Tekirdağ ve Kayseri'de Airbus A 300 tipi uçaklar restoran/kafe olarak yeniden kullanılmaktadır. Konya'da Büyükşehir Belediyesi tarafından 2016 yılında yapılan ve merkezi konumunda yer alan uçak restoran/kafe 295 kişilik kapasite ile çalışmaktadır (URL-26) (Şekil 11a-11b). Hurda uçaklardan oluşturulan kafe/restoran projeleri büyük merak uyandırması sayesinde yapıldıkları bölgelerin turizm açısından gelişmesine ve atık malzemelerin kullanımı hakkında bilincin oluşturulmasına katkı sağlamaktadır.

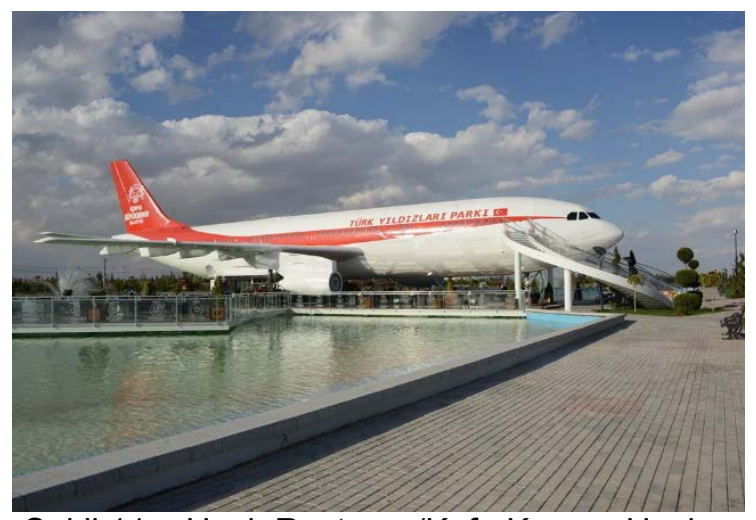

Şekil 11a. Uçak Restoran/Kafe Konya- Uçak restoran genel görünüş (URL-27)

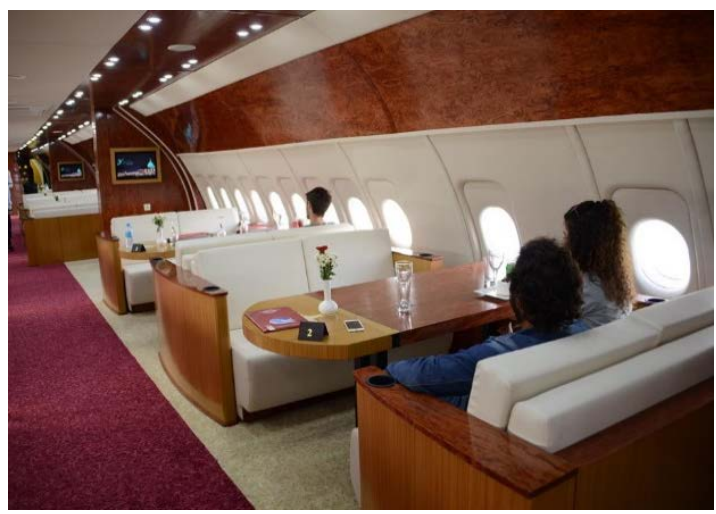

Şekil 11b. Konya uçak restoran/kafe iç mekândan görünüş (URL-27)

\subsection{La Paisanita Refuge projesi (Arjantin)}

La Paisanita Refuge projesi, STC Arquitectos Ofisi tarafından 2020 yılında Arjantin'de inşa edilmiştir. Kırsal alanda peyzaj dokusunu koruyarak oluşturulan konut yapısında kullanılan atık malzemeler, yerel iklime uygun sürdürülebilir çözümler sunmaktadır ve çevresel olumsuz etkilerin azaltılmasına katkı sağlamaktadır (URL-28). Proje, yükseltilmiş ahşap zemin, yaşam alanının olduğu bir kutu ve gölgelik görevi gören metal çatı taşıyıcı elemanı olmak üzere üç unsurdan oluşmaktadır. Yükseltilmiş zemin, atık ahşap malzemenin yeniden kullanımı ile oluşturulmuştur ve inşaat alanlarından kazanılan metal profiller ve petrol boruları ise taşıyıcı sistemde kullanılmıştır (Şekil 12a). Çatı ve yaşam alanının cephesinde eski bir tarla kulübesinden elde edilen atık oluklu metal levha kullanılmıştır (Şekil 12b). La Paisanita Refuge projesinde ekonomik, basit ve bakım gerektirmeyen atık malzemelerin kullanımı ile mimarın/tasarımcının 
yeniden kullanım ve geri dönüşüm konusunda farkındalık oluşturma çabası ve bilinci görülmektedir (URL-29).

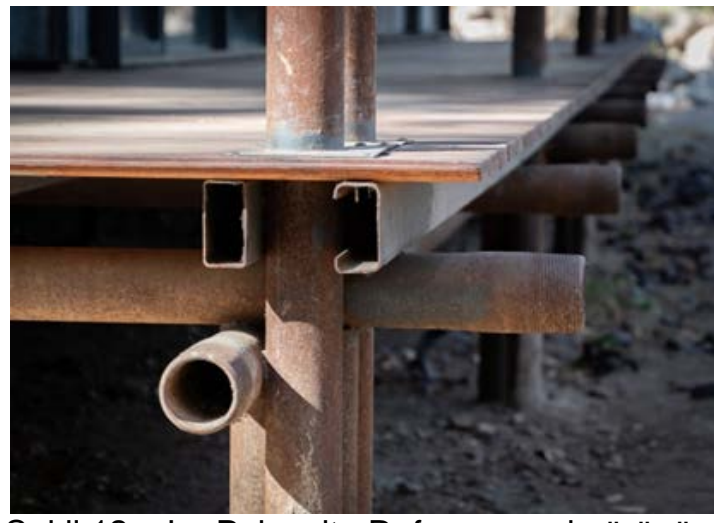

Şekil 12a. La Paisanita Refuge genel görünüş (URL-28)

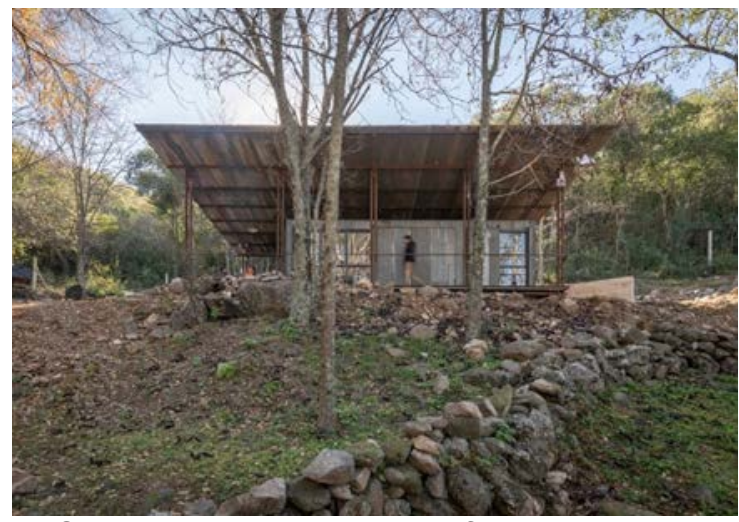

Şekil 12b. La Paisanita Refuge yükseltilmiş zemin detayı (URL-28)

\section{Değerlendirme ve Sonuç}

İnşaat sektöründeki artış ile birlikte üretim ve tüketim arasındaki dengenin kurulamaması sonucu giderek artan atık miktarı, yeniden kullanım ve geri dönüşüm üzerine çalışmaların yapılmasını gerekli kılmaktadır. Ayrıca hammadde kaynaklarının sınırlı olmasından dolayı yapılaşma ile birlikte artan malzeme kullanımının dikkatli ve planlı gerçekleştirilmesi oldukça önemlidir. Kaynakların korunması için malzemenin yeniden kullanım ve geri dönüştürülerek değerlendirilmesi anlayışının öneminin anlaşııması ve çalışmaların yaygınlaştırılması gerektiği düşünülmektedir.

Çalışmada, atık metallerin yeniden kullanımı ve geri dönüşümü hakkında mimarın/tasarımcının sorumluluklarına değinilmektedir. Malzemenin kullanım ömrü sonu yeniden kullanımı ya da geri dönüşümü mimara/tasarımcıya ve müşteriye bağlıdır. Mimar/tasarımcı topluma bu konuda örnek olmalı, tasarımlarında yeniden kullanıma uygun ve geri dönüştürülmüş malzeme tercihlerinde bulunmalıdır. Sadece bu tür malzemeleri değil, aynı zamanda tasarımda aşamasında seçilecek ürünlerin geri dönüştürülebilme potansiyellerini de dikkate almalıdırlar.

Bu kapsamda yapı ve farklı sektörlerden elde edilen atık metallerin yeniden kullanımı ve geri dönüşümü üzerine kentsel ve mimari ölçekte incelenen proje örneklerinin çıkarımları aşağıda özetlenmiştir. İncelenen örnekler; yeniden kullanım veya geri dönüştürülmüş malzemenin araştırılması, bulunması, tedarik edilmesi, kullanıma uygun hale getirilmesinin ve tasarıma dahil edilmesinin kolay bir süreç olmadığını, yeni malzemeye oranla çok daha kısıtlayıcı bir etkiye sahip olduğunu ancak yenilikçi çözümleri de beraberinde getirdiğini ortaya koymaktadır.

- Recycloop, Casa Pollo ve La Paisanita Refuge projelerinde; atık yapı malzemeleri ile kentsel bir kültür merkezinden, konuta kadar her ölçekte projenin yapılabileceği görülmektedir. Evyelerden oluşan tasarım, kullanıcılar tarafından dikkat çekmekte ve böylece atık malzemenin kullanımı konusunda gerekli bilincin oluşturulmasına da katkıda bulunmaktadır. Projenin ölçeğinin ve kullanılan malzemenin ne olduğunun önemli olmadığı, ortaya çıkan tasarımın mimarın/tasarımcının hayal gücü ve bilgisi dâhilinde meydana geldiği anlaşılmaktadır. Mimarın/tasarımcının atık malzemeyi tasarıma entegre etmesi ve süreç içindeki rolü bakımından Recycloop projesinde; 
mimarın/tasarımcının tasarım aşamasında seçtiği malzemenin esnekliği ve uyarlanabilirliğinin avantajı sonucu, proje işlevi sonunda sökülerek farklı ölçeklerde ve işlevlerde yeniden kullanılabileceği deneyimlenmiştir. Mimarın/tasarımcının Casa Pollo projesinde kullandıkları atık çinko plakaları farklı projelerine de dâhil etmeleri, atık malzemenin kullanım potansiyelinin farkında olduklarını göstermektedir. La Paisanita Refuge projesinde ise, mimar/tasarımcı atık malzemenin potansiyelini göstermek ve bu konuda bilinç oluşturmak için malzeme seçimlerinde bulunduğu görülmektedir.

- Konteynır Park, Temp'l ve Waste Delivery Station projeleri değerlendirildiğinde; tasarımda kullanılan farklı atık malzemelerden oluşturulan bu projelerin, yüksek ücretli malzemeler kullanılarak yapılan tasarımlardan bir farkının olmadığı; işlevsel, çevreci ve ekonomik olarak tasarlandığı görülmektedir. Konteynır, gemi parçaları ve otomobil sac plakaları gibi farklı sektörlere ait atık metal malzemelerin de mimari tasarıma dâhil edilebileceği anlaşılmaktadır. Konteynır gibi sıklıkla kullanılan bir malzeme ile tasarım yapılabilirken, otomobil sac plakalar gibi kullanım sonu işlevsiz kabul edilen malzemelerin de değerlendirilebileceği görülmektedir. Projelerde, atık malzemelerin kullanımıyla oluşturulan mimari mekânlar ve toplum arasında bağlantının kurulmasına önem gösterildiği gözlemlenmiştir. Mimarın/tasarımcının atık malzemeyi tasarıma entegre etmesi ve süreç içindeki rolü bakımından bu projeler incelendiğinde; Konteynır Park projesinde mimar/tasarımcı, müşterinin taleplerini ve intiyaçlarını karşılamak amacıyla malzeme arayışına girdikleri ve gerekli araştırmalar sonucu intiyaçlarını yakın çevreden (İzmir Limanı) temin ettikleri görülmüştür. Bu durum mimarın/tasarımcının atık malzemeyi tasarıma entegre etmek için bilinçli kararlar verdiklerini gözler önüne sermektedir. Templ projesinde, mimarın/tasarımcının tasarım aşamasında yeniden kullanım ve/veya geri dönüşüm kapsamında bilinç oluşturmak ve atık malzemenin sergilediği çevreci, estetik etkinin anlaşılması amacı, ilgi çekici atık malzeme arayışına neden olmuştur. Bu amaç mimarın/tasarımcının atık malzeme konusundaki sorumluluklarının farkında olduklarını aynı zamanda toplumu da bu konuda bilgilendirme isteklerini göstermektedir. Waste Delivery Station projesinde ise, atık malzeme kullanımını müşterinin talep etmesi, tasarım aşamasını tersine çevirmiş ve atık malzemeler tasarıma yön verecek konuma evrilmiştir.

- 747 Wing House ve Uçak Restoran/Kafe projelerinde; atık metal uçak parçalarının geri kazanımı üzerine farklı tür ve konumdaki örnekler bulunmaktadır. Proje örnekleri, belediye ya da özel müşterinin atık malzeme konusundaki talebi sonucu ortaya çıkan güçlü bir birlikteliği yansıtmaktadır. Kullanım ömrünü tamamlamış uçakların ya da uçak parçalarının değerli bir mimari malzeme haline getirilebileceği görülmektedir. Mimarın/tasarımcının atık malzemeyi tasarıma entegre etmesi ve süreç içindeki rolü bakımından projeler incelendiğinde; 747 Wing House projesi, mimarın/tasarımcının yeniliklere açık olması ve bu kapsamdaki arayışı ile müşterinin taleplerine cevap verecek bir tasarım ortaya koyma amacı, yakın çevreden satın alınan atık metal uçak parçalarının tasarıma dâhil edilmesini sağlamıştır. Mimarın/tasarımcının bu konudaki bilinç seviyesi ve atık yönetimi malzemenin israfının önüne geçerek farklı işlevlerde ve mekânlarda uçak parçalarının kullanımına olanak vermiştir. Ülkemizde Konya'da hayata geçirilen Uçak Restoran/Kafe projesinde ise, yerel yönetimin hurda uçağın potansiyelini fark etmesi ve satın alması projeye yön vermiştir. Bununla birlikte farklı konumlarda ilgi çeken uçak restoran/kafeler 
turizm bakımından şehirlerin ekonomik olarak kalkınmasına da katkı sağlamaktadır.

- Doğuş Lojistik D Cafe ve Luxury Pavilion projelerinde de; hurda metalin sadece malzemenin yeniden kullanımı yöntemi ile değil, geri dönüşüm işlemlerinden sonra da projelere dâhil edilebildiği görülmektedir. Projelere dâhil edilen yeniden kullanıma uygun hurda metalin yüksek geri dönüştürülme potansiyeline sahip atık kategorisinde değerli bir malzeme olduğu da unutulmamalıdır. Ayrıca mimarın/tasarımcının tasarım aşamasında, yapının kullanım ömrü sonunda ne şekilde geri kazanılabileceğini düşünmesi sürdürülebilir bir gelecek için ne kadar değerli olduğu anlaşımıştır. Mimarın/tasarımcının atık malzemeyi tasarıma entegre etmesi ve süreç içindeki rolü bakımından projeler incelendiğinde; Doğuş Lojistik $D$ Cafe projesinde mimarın/tasarımcının geri dönüştürülmüş malzeme kullanımı bu proje ile sınırlı kalmamaktadır ve bu durum bilinçli tercihler yaptıklarını göstermektedir. Luxury Pavilion projesinde, mimarın/tasarımcının yeniden kullanım ve/veya geri dönüşüm konusunda farkındalık oluşturma amacı isteği, tasarım aşamasında gerekli araştırmaları yapmalarına neden olmuştur. Tasarım ekibinin atık yönetim şirketi Bee'ah'e ile işbirliği yapması atık malzeme kullanımında disiplinlerarası ilişki ve aktörlerin rolünü göstermektedir. Atık yönetim planlanması sayesinde pavilion, kullanım sonunda Bee'ah'e geri dönüştürülmek için gönderilmiştir.

Genel sonuç olarak, incelenen projelerde atık metal malzemenin yeniden kullanım yoluyla tasarıma dâhil edilme potansiyelinin daha yüksek olduğu ve bu potansiyelin mimar/tasarımcı elinde değerli kullanımlara dönüştüğü görülmektedir. Ancak yeniden kullanım dışında geri dönüştürülmüş ya da geri dönüştürülme potansiyeline sahip metal malzemenin projelere dâhil edilmesinin de önemli avantajları bulunduğu ve bu nedenle bu tür örneklerin yaygınlaştırıması gerektiği düşünülmektedir. İncelenen farklı işlevlere sahip projelerdeki ortak amacın, sürdürülebilir mimarlık anlayışına ve çevresel problemlere yenilikçi bir açıdan farkındalık oluşturmak istendiği anlaşılmaktadır. Projeleri gerçekleştiren mimarın/tasarımcının atık metal malzemenin yeniden kullanımı ve geri dönüşümünün yanında farklı atık malzemeleri de tasarımlarının parçası haline getirdikleri gözlemlenmiştir. Bu tasarımlar mimarın/tasarımcının sürdürülebilir mimarlık kapsamında atık malzemeler ile çalışarak çevresel problemler üzerindeki sorumluluklarının bilincinde olduklarını göstermektedir.

Türkiye'de atık metallerin yeniden kullanımı ve geri dönüşümü uygulamalarının bulunduğu örnekler olmasına rağmen, literatürdeki çalışmaların kısıtlı olduğu belirlenmiştir. Bu çalışma ile konu hakkında bilincin oluşmasında ve atık metallerin değerlendirildiği örneklerin yaygınlaşmasında mimarın/tasarımcının rolünün ne kadar önemli olduğu vurgulanmaya çalışılmıştır. 


\section{Kaynaklar}

Ahmad, Sani Aminu; Saliu, Hassan Ozovehe; Mustapha, Sani; Sarkile, Kawuwa Abubakar, "Trash to Treasures Exploring 'Re-Material' in Architecture As A Means of Reducing Waste Generated in Urban Centers", International Joint Conference on Sustainability and Development, 21st-24th March 2016, Nigerya 2016, s. 1-9.

Altındağ, Saffet, İstanbul'da Hafriyat Toprağı, Inşaat ve Yıkıntı Atıklarının Tersine Lojistik Yöntemiyle Alternatif Yönetim Planı, Yüksek Lisans Tezi, İstanbul Teknik Üniversitesi, Fen Bilimleri Enstitüsü, İstanbul 2011, s.1-61.

Arslan, Hakan; Coşgun, Nilay; Salgın Burcu, "Construction and Demolition Waste Management in Turkey", Chapters in Waste Management - An Integrated Vision, Luis Fernando Marmolejo Rebellon (Ed.), InTech Open, Rijeka 2012, s. 313-332.

Buzkan, Ceyda; Erman, Onur, "Yapısal Atıkların Geri Dönüşüm Sorunu ve Türkiye'deki Durumun Mevzuat Bakımından Değerlendirilmesi", Doğal Afetler ve Çevre Dergisi, 6(1), 2020, s. 76-89.

Coşgun, Nilay; Güler, Tuğba; Doğan, Belgin, "Yapısal Atıkların Önlenmesinde/Azaltılmasında Tasarımcının Rolü", Mimarlık Dergisi, Mimarlar Odası Yayınları, Sayı: 348, 2009, s.75-78.

Demirarslan, Sibel; Demirarslan, Oğuz, "Sürdürülebilir Çevre Uygulamalarında Mimarın Rol ve Sorumluluğu", Anadolu Doğa Bilimleri Dergisi, 6(2), 2015, s. 220-230.

European Metals Associations, "Metals For Buildings-Essential\&Fully Recyclable", https://www.metalsforbuildings.eu/assets/pdf/bd5643ba39/MFB-leaflet-LR-EN.pdf, (Son erişim tarihi: 10.04.2020), 2011, s.1-6.

Fırat, Fatih Kürşat; Akbaş, Fahri, "İnşaat Endüstrisinde Geri Dönüşüm Çalışmalarının Geliştirilmesi ve Ekonomi Üzerine Etkileri", International Conference on Eurasian Economies, Session 4D: Environment and Energy, 2015, s. 637-644.

Bozoğlu, Baran, "Yönetmelik Var, Uygulama Yok", EGIAD Yarın Dergisi, İzmir, Sayı:63, 2019, s.34-39.

Gündüzalp, A. Anı; Güven, Seval, "Atık, Çeşitleri, Atık Yönetimi, Geri Dönüşüm ve Tüketici: Çankaya Belediyesi ve Semt Tüketicileri Örneği", Hacettepe Üniversitesi Sosyolojik Araştırmalar E-Dergisi, 2016, Şubat, s. 1-19.

Kılıç, Onur, "Mimaride Atık ve Geri Dönüştürülen Malzemelerin Rolü", The Journal of Academic Social Science, Yıl: 5, Sayı: 53, 2017, s. 529-533.

Kozminska, Urszula, "Circular Design: Reused Materials and The Future Reuse of Building Elements in Architecture. Process, Challenges and Case Studies", Chapter in : 
IOP Conference Series Earth and Environmental Science, IOP E-Book Publishing, Volume:225, Brussels 2019, s.1-8. doi:10.1088/1755-1315/225/1/012033.

Munn, Stephanie; Soebarto, Veronica, "The Issues of Using Recycled Materials in Architecture", The 38th International Conference of Architectural Science Association ANZAScA, Issue Context of Architecture, Launceston, Tasmania, 2004, s.161-167.

Norgate, Terry E; Jahanshahi, Sharf; Rankin, William J., "Assessing The Environmental Impact of Metal Production Processes", Journal of Cleaner Production, 15(8-9), 2016, s.838-848.

Öcal, Yasin, Demir Çelik Sektöründe Atık Yönetimi, Uzmanlık Tezi, T.C Kalkınma Bakanlığı, 2014, s. 1-176.

Paker, Berfin; Taş, Nilüfer, "Sürdürülebilir Yapım Sürecinde Mimarın Yapısal Atık Oluşumuna Etkisinin İrdelenmesi: Bursa Örneği”, Yalvaç Akademi Dergisi, 2(1), 2017, s. 88-98.

Salgın, Burcu; Coşgun, Nilay; Aydın İpekçi, Cahide; Tıkansak Karadayı, Tülay. "Turkish Architects' Views on Construction And Demolition Waste Reduction in The Design Stage", Environmental Engineering and Management Journal, 19(3), 2020, s. 439-542.

Taşçı, Burcu Gülay; Tokuç, Ayça, "Yeniden Kullanılabilir Malzeme İle Mimarlık Deneyimi”, Ege Mimarlık Dergisi, Mimarlar Odası İzmir Şubesi, Sayı: 89-90, 2015, s. 24-29.

Tandoğan, Okşan, "Atık Malzemelerinin Mimaride Kullanımı", Ulusal Çevre Bilimleri Araştırma Dergisi, 1(4), 2018, s. 189-202.

Tuna, Bülend, "Doğa, Kent ve Sürdürülebilirlik Bağlamında Mimarın Sorumluluğu", Mimar.ist Dergisi, Mimarlar Odası İstanbul Büyükkent Şubesi, Yıl:9, Sayı:12, 2009, s. 1-112.

URL-1, Hurda, Türk Dil Kurumu, https://sozluk.gov.tr/, (Son erişim tarihi: 11.05.2021, 11:30).

URL-2, Hizmetler, http://dervisogullarihurda.com/Services.html, (Son erişim tarihi: 11.05.2020).

URL-3, Hurda Alımı, https://ozdurumetal.com/, (Son erişim tarihi: 11.05.2020).

URL-4, Metal Hurdacılık, https://www.demirkiranmetal.com/\#page-content, (Son erişim tarihi: 11.05.2020).

URL-5, Hizmetler, https://www.gursoygeridonusum.com/site/index.html\#, (Son erişim tarihi: 11.05.2020). 
Sürdürülebilir Mimarlık Bağlamında Metal Malzemenin Yeniden Kullanımı ve Geri Dönüşümünde Mimarın/Tasarımcının Rolü Architect/Designer's Role on the Reusing and Recycling of Metal Materials in Terms of Sustainable Architecture

URL-6, Metal Geri Dönüşümü, http://www.turkchem.net/metal-geri-donusum.html, (Son erişim tarihi: 20.06.2020).

URL-7, 2012 Architecten, https://www.spatialagency.net/database/2012.architecten, Son erişim tarihi: 02.03.2020).

URL-8, Superuse principles, https://www.denisguzzo.com/projects/superusel, (Son erişim tarihi: 08.04.2020).

URL-9, Junkitecture, https://www.fastcompany.com/1521728/junkitecture, (Son erişim tarihi: 20.07.2020).

URL-10, Building made entirely of recycled kitchen sinks, https://inhabitat.com/buildingmade-entirely-of-kitchen-sinks/, (Son erişim tarihi: 02.03.2020).

URL-11, Superuse Studios, Recycloop, https://www.flickr.com/photos/2012architecten/503344992/in/album$\underline{72157600227815063 /}$, (Son erişim tarihi: 02.03.2021, 13:00).

URL-12, The Luxury Pavilion Built From Recycled Bedsprings, https://www.archdaily.com/884520/the-luxury-pavilion-built-from-recycled-bedsprings, (Son erişim tarihi: 08.04.2020).

URL-13, D3 Abwab Pavilion, https://www.fahedarchitects.com/exhibition-installation, (Son erişim tarihi: 08.04.2020).

URL-14, Sustainability consulting, https://davidhertzfaia.com/services, (Son erişim tarihi: 20.07.2020).

URL-15, 747 Wing House/David Hertz Architects, https://www.archdaily.com/165172/747-wing-house-david-hertz-architects, (Son erişim tarihi: 12.04.2020).

URL-16, Konteyner Park, https://atolye.io/tr/proje/konteyner-park-2l, (Son erişim tarihi: 02.03.2020).

URL-17, Konteyner Park (Mercan), http://www.arkiv.com.tr/proje/konteyner-parkmercan/5570, (Son erişim tarihi: 20.07.2020).

URL-18, Container Park/ATÖLYE, https://www.archdaily.com/778903/container-parkatolye-labs, (Son erişim tarihi: 20.07.2020).

URL-19, Doğuş lojistik d cafe, Türk Yapısal Çelik Derneği, https://www.tucsa.org/tr/celik yapilar yazi.aspx?yazi=680, (Son erişim tarihi: 24.07.2020).

URL-20, MoMA'nın Paslı Gemisi, https://www.arkitera.com/haber/momanin-pasligemisil, (Son erişim tarihi: 10.04.2020).

URL-21, YAP Seoul-Temp'L/shinslab architecture, 
https://www.archdaily.com/792602/yap-seoul-nil-templ-shinslab-architecture,

(Son erişim tarihi: 10.04.2020).

URL-22, Chile's rustic Casa Pollo is made from recycled zinc plates and reclaimed wood, https://inhabitat.com/chiles-rustic-casa-pollo-is-made-from-recycled-zinc-platesand-reclaimed-wood/casa-pollo-by-ortuzar-gebauer-arquitectos-3/, (Son erişim tarihi: 19.07.2020).

URL-23, Casa Pollo/Ortuzar Gebauer Arquitectos, https://www.archdaily.com/887654/casa-pollo-ortuzar-gebauer-arquitectos, (Son erişim tarihi: 19.07.2020)

URL-24, Afvalbrengstation,

https://www.wesselvangeffenarchitecten.nl/projecten/afvalbrengstation-2.html, (Son erişim tarihi: 19.07.2020)

URL-25, Afvalbrengstation, Den Haag,

https://www.bouwenmetstaal.nl/publicaties/nieuwsbrief-architect-staal/architect-staalapril-2017/afvalbrengstation-denhaagl, (Son erişim tarihi: 10.04.2020).

URL-26, Türkiye'deki Uçak Konseptli Restoranlar, https://blog.biletall.com/turkiyedekiucak-konseptli-restoranlar, (Son erişim tarihi: 15.04.2020).

URL-27, Hurda uçaktan yapılan kafe hizmete açıldı, https://www.ntv.com.tr/galeri/ekonomi/hurda-ucak-luks-restoranoldu,4Bq1x5dTW0CpayU3XnO7OA/ofnbKW FdEuzRgip R4whg, (Son erişim tarihi: 19.07.2020)

URL-28, La Paisanita Refuge / STC Arquitectos, https://www.archdaily.com/945990/lapaisanita-refuge-stc-arquitectos, (Son erişim tarihi: 20.03.2021, 15:15).

URL-29, STC arquitectos uses recycled oil pipes and metal sheets to create refuge in rural argentina, https://www.designboom.com/architecture/stc-arquitectos-recycled-oilpipes-metal-sheets-refuge-argentina-08-12-2020/, (Son erişim tarihi: 20.03.2021, 15:30). 